\title{
Immigrants' educational credentials leading to employment outcomes: The role played by language skills
}

\author{
María Miyar-Busto \\ UNED \\ mmiyar@poli.uned.es \\ Fco. Javier Mato Díaz \\ U. of Oviedo \\ jmato@uniovi.es \\ Rodolfo Gutiérrez \\ U. of Oviedo \\ rgutier@uniovi.es
}

\begin{abstract}
Transferability of human capital is a key issue in the analysis of immigrants' integration in the destination country, according to both empirical and theoretical literature. In addition to the problem of recognition of immigrants' educational credentials and their lack of social networks, language is highlighted in the literature as a crucial factor regarding buman capital transfer. This paper considers the role played by Spanish language skills in the integration of migrants into the labour market in Spain. It takes advantage of the fact that about half of the immigrant population have Spanish as their native language, and of the diversity levels of fluency in Spanish among the remaining immigrants. Using the Labour Force Survey special module on the labour market situation of immigrants (INE 2015), the research has two purposes: first, to measure the direct effect of language skills on employment outcomes; and second, to analyze the complementary vs. substitution bypotheses regarding the interaction between Spanish language skills and educational credentials as determining factors for employment. The results confirm that skill levels in Spanish have a significant role regarding access to employment. Regarding the complementary vs. substitution hypotheses, interesting gender differences appear that confirm the striking contrasts in the Spanish labour market for female and male immigrants. For men, their level of Spanish acts as a complement to their educational qualifications in belping them to obtain employment, but this is not the case for women. However, female immigrant workers seem to obtain higher employment returns on their educational qualifications than men when it comes to avoiding very low-skilled jobs.
\end{abstract}

Keywords: immigration, language, buman capital, employment, Spain. 


\section{Introduction}

In this paper we analyze the role played by language skills in the labor market integration of immigrants in Spain. Particularly, we analyze how language ability can help immigrants to access employment and to avoid the lowest-level occupations in the labour market, where a vast majority of immigrants find jobs in the Spanish labour market. For many migrants, a lack of skills in the host country's language can build an insurmountable barrier to entering the labour market.

Furthermore, we consider two dimensions of the effect of language on labour market outcomes. First, language abilities can increase directly the probability of being employed in general and of being employed in non-unskilled occupations. Second, we explore the complementarity effect of language and educational level, taking into account the problems of human capital transferability that migrants face when they change their country of residence (Friedberg, 2000). Together with country-specific skills and credential recognition, language abilities are one of the main factors preventing the transfer of human capital across countries. We also differentiate this hypothetical complementarity between language and human capital for men and women, taking into account that the strong segmentation of migrant female workers in Spain can introduce additional constraints to the use of human capital (women are employed almost exclusively in occupations with very low human capital requirements but with significant personal interaction, such as domestic service jobs).

The structure of the paper is as follows. The next section provides a general explanation of the reasons that make Spain an interesting case for studying the role of language in labour market outcomes. After this, the state of the art regarding this area of research is presented and some hypotheses are formulated accordingly. The following section presents the data, variables and methods that have been used, which are followed by an analysis of the main results. The final section provides the study's conclusion.

\section{A remarkable setting for studying returns on language skills}

Most research on the role played by language in immigrants' abilities to obtain employment has looked at post-war migration to North America and Central and Northern Europe during the 1960s and 1970s. In those studies, the destination countries had long traditions of immigration and their labour markets had a very diverse map of occupations, requiring low, medium and high levels of skill 
or qualification. Post-1989 flows, specifically those to Southern Europe, show different patterns to post-war migration in terms of migrants' origins, gender and education, the basic traits of labour markets, and the immigration policies in host countries (González-Enríquez and Triandafyllidou, 2015).

There are more specific reasons why analyses of the employment attainment by immigrants in Spain is interesting, because the country presents a unique combination of features that are rarely found in those countries that were the main migratory destinations in recent times. This singularity of the Spanish case generates something of a paradox as it encompasses one of the largest migratory flows in the past few decades to a country that lacks a "migratory model". This lack of a model has been pointed out by several authors (Cebolla and González Ferrer, 2013; Izquierdo and Cornelius, 2012) who analyse the absence of a set of institutional and public policy devices explicitly arranged to guide, select and host these flows.

In fact, there are four specific features in the Spanish case that deserve attention. First, Spain is a country that had had no tradition of immigration prior to the extraordinary boom in the 2000s. Between 1998 and 2012 (the peak year of immigrant stock), Spain registered an increase of 5.6 million in the number of its population born abroad (Figure 1). Most of this population has stayed in Spain in spite of the severity of the crisis and the large increase in unemployment. At the beginning of 2018 this population amounted to 6.4 million, only 0.4 million less than in 2011. That made it the country with the third largest increase in that number worldwide, after only the United States and Germany. Even in the peak years of the crisis (2011-2013), with an unemployment rate close to $25 \%$, an average of over 300,000 immigrants entered Spain a year; in 2017, which was officially designated the third year of economic recovery, the entries amounted to 532,000 people, a similar figure to that observed in the mid-2000s.

Second, immigration to Spain consists of large groups from all continents who therefore vary considerably in the extent to which they differ culturally and linguistically from the native population. There is a high proportion of people from Central and South America, the vast majority of them with Spanish as their mother tongue, which largely explains their choice of this destination (Alonso and Gutierrez, 2010; Adsera and Pytlikova, 2015). Their numbers in terms of percentage of the migrant workforce have remained quite stable: the National Survey of Immigrants carried out in 2007 registered 45 per cent of immigrants as having Spanish language as their mother tongue, while 8 years later in 2015 the Labour Force Survey (EPA) module registered 50 per cent with the same origin (Table 1). 
The next largest group is that of immigrants from Eastern Europe, with a strong predominance of Romanian nationals numbering 593,532 people according to the Padrón (Population Register) in early 2018. The size of this group, whose mother tongue is also a Romance language, explains why almost half of non-native-Spanish-language immigrants have reached a high level of Spanish fluency in a short period of stay: in 2007, 31 per cent of immigrants with a non-Spanish mother tongue showed a good level of fluency, while in 2014 they amounted to 51 per cent.

After these groups are immigrants from Africa, most of whom have Moroccan Arabic as their mother tongue. This group added up to 824,621 people in 2018. There is also a large group from the sub-Saharan region of Africa, with a variety of mother tongues, but their number is less than a quarter than that of the Moroccans. Asia is the continent with the smallest presence in terms of immigration to Spain, as well as with the greatest cultural distance. Nevertheless, Asian immigrants add up to 500,000 people, China being the largest national group, with 195,193 people in 2018. It is worth noting that, while Hispanic inflows have fallen during the economic crisis, immigrants from other continents, such as Romanians, Moroccans and Chinese, have continued to rise.

This migration, although recent, has been going on for long enough to enable the analysis of levels of assimilation and labour mobility among groups, although this is tempered by a significant number of recent arrivals, which means that length of residence has to be considered a highly influential variable in these processes.

Third, the Spanish labour market, particularly during the period when immigration was peaking, has been characterized by a very high proportion of unskilled occupations and a sharp split along the lines of insider-outsider workers (Bentolila, Dolado and Jimeno, 2011). The boom in immigration to Spain coincided with a period of marked growth in activities requiring high amounts of unskilled labour, such as construction, tourism and personal services. At the time, and associated with the migration boom itself, not only did the insideroutsider split continue, but it was actually exacerbated by the failure of reforms aimed at making the Spanish labour market more flexible. In that environment, it was reasonable to expect that immigrants' assimilation into the Spanish labour market would be especially segmented.

But this situation -and this is the fourth trait-, reversed completely with the recession that began in 2007. A large amount of immigrants, most of them in the initial stage of labour market assimilation, had to confront huge employment losses, which were especially intense for low-qualified jobs. This situation of an 
immigrant population that experiences two intense economic cycles of growth and recession has been not so common in other reception countries.

To summarise, therefore, the four peculiarities that characterise the Spanish experience are: the intensity of the phenomenon, which has taken place in a country with no tradition of immigration; the arrival of immigrants from a variety of cultural and linguistic backgrounds in sufficient numbers for analysis; their entry into a labour market with a relatively low level of skilled occupations and not much flexibility; and the effect of two intense economic cycles on employment outcomes. All these factors make Spain a particularly interesting country for investigating whether the attainment of employment among immigrants follows the dominant patterns identified in the literature.

Figure 1. Foreign-born population in Spain (thousands), 1998-2019

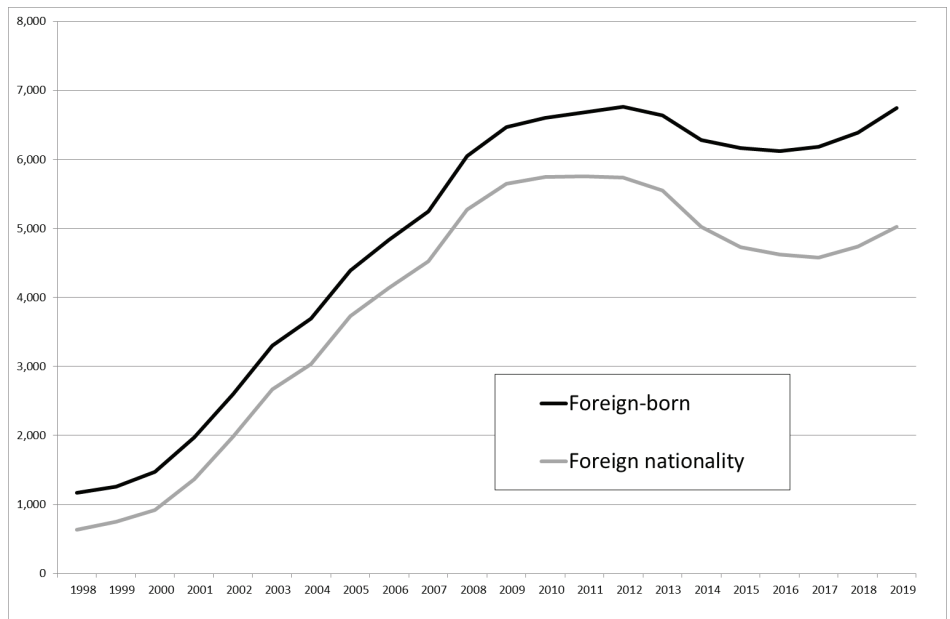

Source: INE, Padrón Continuo.

Table 1. Distribution of foreign-born population residing in Spain by mother tongue and by Spanish language fluency

\begin{tabular}{|l|c|l|c|}
\hline \multicolumn{2}{|c|}{ ENI 2007 } & \multicolumn{2}{c|}{ EPA 2014 } \\
\hline Mother tongue & 45 & Mother tongue & 50 \\
\hline Other language & 55 & Other language & 50 \\
\hline Very good & 31 & Advanced & 51 \\
\hline Good & 27 & Intermediate & 32 \\
\hline Sufficient & 12 & Beginner & 16 \\
\hline Need to improve & 14 & Unable to assess & 100 \\
\hline Notable & 16 & Total other language & \\
\hline Total other language & 100 & & \\
\hline
\end{tabular}

Source: INE, Encuesta Nacional de Inmigrantes 2007 and Modulo EPA sobre situación laboural de los inmigrantes 2014. 


\section{Lack of language proficiency as a barrier to human capital transferability}

The relationship between immigrants' language skills and their success in the labour market has been a popular topic for economic and sociological analysis during the last three decades. As outlined by Grin (2003), this research has been divided between four main focuses of interest, corresponding to the most typical situations of competition between languages as a result of immigration: (a) discrimination based on an individual's belonging to a linguistic community, usually that of their first language; (b) the estimated value of a second language when it is demographically dominant in a territory, the most typical situation being that of immigrants who do not speak the language of their host country; (c) the estimated value of knowing a foreign or second language, when it is not demographically dominant in the relevant territory, for which the most common cases are, on the one hand, residents of a country (e.g., France) who acquire knowledge of a foreign language (e.g., Spanish), and, on the other hand, situations of territories with official bilingualism, in which persons of a particular linguistic community (e.g., speakers in Spanish) acquire competence in another official language of that country (e.g., Catalan); and (d) the study of immigrants' use of their mother tongue in their destination country, a situation that can be generalized to all immigrants who do not share a language with their territory of destination.

This study corresponds to type (b), that is the benefits that immigrants derive from having a command of their host country's language. These studies dominate the empirical literature on this topic and have a clear theoretical foundation: knowledge of the language of the destination country is a basic component of human capital. Research has shown that this resource contributes positively to higher levels of attainment in the labour market and, in particular, higher income (Chiswick and Miller, 2014).

The bulk of this literature has studied immigration in Anglo-Saxon countries and the potential advantages of knowing English for immigrants who are not native speakers. This literature has found some key findings. The classic studies by Chiswick and Miller proved that reading fluency in English is more important than speaking fluency as a determinant of earnings among immigrants to the US (Chiswick and Miller, 1991). The same authors extended their analysis to comparisons of immigrants coming to Australia, to the US, to Canada and to Israel, who faced the problem of endogeneity between job achievement and linguistic acquisition (Chiswick and Miller, 1995). Dustman and Fabri (2003) 
addressed possible biases in self-assessed measures of language skills and found that fluency in English among immigrants into the UK increases employment probability by about 22 percentage points. Also in the UK, Shields and Wheatley Price (2001) concluded that immigrants' fluency in English leads to a higher probability of employment of around 20 to 30 percent. Bleaky and Chin (2003) looked into US immigration, finding a significant positive effect of Englishlanguage skills on wages among individuals who immigrated as children. A large portion of this effect was due to increased years of schooling. In contrast, adult English-language classes seemed to be insufficient in helping immigrants' wages to converge with those of natives.

Despite the importance of immigration in continental Europe, research on the subject in other European countries has been quite scarce until quite recently (Heckmann, and Schnapper, 2003; Zimmerman, 2005). In Germany, Dustmann (1994) and Dustmann and van Soest (2001; 2002), using data from different waves of a longitudinal panel, found an earnings premium related to German speaking proficiency of at least five percent; addressing the endogeneity problem, the earnings premium could be three-times higher than this, at around 15 percent. Lochmann et al.- (2018) examined the impact of language training on the economic integration of immigrants in France, where this kind of training is provided as a public service for newly arrived immigrants who obtain low scores in an initial language exam. They found that the number of hours of this training significantly increased the labour force participation of treated individuals, although the impact on women and individuals with low levels of education was relatively small.

In Spain, it has hardly been possible to address this issue until recently. Most research has been carried out without direct measures of Spanish-language proficiency among the immigrants; in place of this, it has tended to use the continent of origin and length of stay as proxy variables for cultural distance and probability of having acquired a command of Spanish, respectively (AmuedoDorantes and de la Rica, 2007). The results of these investigations provide an image in which place of origin effectively conditions immigrants' levels of success in terms of employment, wages and occupational mobility, although it fails to conclusively demonstrate a consistent advantage for immigrants who have Spanish as their mother tongue. Fernández and Ortega (2008) have shown, using data from the Labour Force Survey (Encuesta de Población Activa) for the period 1996-2005, that there are significant differences in employment levels among immigrant labourers from different backgrounds (non-EU Europeans, Latin Americans and Africans). Those of Latin-American origin have, both in the initial 
stage and after five years of residence, higher rates of activity than natives and immigrants of African origin. However, the labour market participation of this group and their levels of over-education are below those of non-EU European immigrants, both on arrival and after five years of work experience in Spain.

In the past few years, various papers have used the 2007 National Survey of Immigrants (NSI). For example, empirical evidence from the survey shows that proficiency in Spanish improves access to employment and skilled occupations (Mato and Gutiérrez, 2010; Budria et al, 2018), earnings (Mato and Gutiérrez, 2010; Budría and Swedberg, 2015), social assimilation (Gutiérrez and Miyar, 2010) and occupational mobility (Simon, Sanromá and Esteban, 2011).Also using NSI data, Budría and Swedberg (2015) discover a strong positive relationship between multilingualism and language skills among immigrants in Spain.

A particularly important topic in the available literature is the likely relationship between language proficiency and educational achievement. These may be complementary factors as regards their influence on labour market outcomes (Budria and Swedberg, 2015). First, language skills are likely to be highly valued, in relative terms, in jobs that require a comparatively high education level. Second, a low educational level may also affect other life skills that influence access to the labour market (e.g., creating social networks). Third, employers may take immigrants' language proficiency as a sign of the effective quality of the professional training acquired by each person. However, evidence of this complementarity is not conclusive and, while there are results showing relatively higher returns on language proficiency among those employed in high-skilled occupations (Berman et al., 2003), other research results have produced varying degrees of complementarity among different groups (Chiswick and Miller, 2013; Budria and Swedberg, 2015). This provides an opportunity to analyse alternative relationships between language skills and educational achievement, such as additive or substitution effects.

The diversity of results regarding returns on education obtained by different immigrant groups has also been related, among others, to whether education was acquired in the country of origin or at destination. Human capital acquired at origin, both generic capital represented by credentials, and specific capital in the form of work experience, may not have the same value as that obtained in the country of destination. Several studies have shown the effect of non-perfect portability of human capital obtained originally by immigrants in different destinations (Freidberg, 2000; Chiswick and Miller, 2009; Basilio and Bauer, 2010). A similar effect was also observed in Spain when looking into immigrants' wages, with strong heterogeneity according to origin (Sanromá, Ramos and 
Simon, 2015); one result that stands out is that immigrants of greater cultural (European countries) and linguistic proximity (Latin American countries) obtain higher returns on their previously acquired human capital compared to immigrants arriving from other countries. ${ }^{1}$

The influence of gender is well proven in research on human capital and the labour achievements of immigrants. However, the research that deals with human capital and its interaction with linguistic competences has paid less attention to differences according to gender, something that has been studied by Basilio, Bauer and Kramer (2010) in Germany and Li and Sweetman in Canada (2014). This relatively low attention to gender may be due to the fact that the post-war migratory cycle was composed mostly of men. In the most recent cycle of immigration to Southern Europe, and in particular Spain, that composition has been more balanced. In addition, in these countries the insider-outsider dynamics of the labour market are closely associated with gender differences, which makes its influence in the Spanish case particularly interesting.

Finally, labour market segmentation, usually very important for migrants (Wilson and Portes,1980; Constant and Massey, 2005) can constitute a barrier to the use of human capital in the host country (Hall and Farkas, 2008). This can be an additional difficulty for female migrants, given the strong segmentation of the Spanish labour market, where women are heavily concentrated in lowskill occupations that, nevertheless, require certain social skills and levels of interaction, such as waiters or domestic service.

In this research context, the present paper looks at the role of Spanish language skills in determining migrants' access to employment, in particular given the important section of immigrant population in Spain that has Spanish as their native language, and given the diverse language skills among the rest of the immigrant population. The research has two objectives: first, to look the direct effect of Spanish language skills on employment outcomes; and second, studying the interrelationship between language skills and education levels regarding access to employment.

\section{Hypotheses}

In order to address the aims of this research, two pairs of hypotheses are proposed. The first pair refers to the direct effect of language skills on labour market outcomes, that is, the probability of being employed and the probability of working in an occupation that is not at the bottom of the occupational pyramid.

H1: Language skills increase the probability of being employed.

1. These results are based on 2007 ENI data. 
H2: For those who are employed, language skills increase the probability of avoiding very low-skilled occupations.

Also, the study also seeks to arrive at a deeper understanding of the interaction between educational achievement and language skills by examining whether language abilities are a complement to or a substitute for formal human capital. Thus, the second pair of hypotheses proposes that language skills provide a catalyst that assists in the transfer of foreign human capital:

H3: Migrants with better language skills obtain a better return on their human capital than migrants who lack these abilities.

H4: The complementary effect of language skills will be smaller in the female labour market than in the male labour market due to segmentation in the former that tends to push women into low-skilled occupations requiring communicative skills.

\section{Data, variables and methods}

Micro-data from the Spanish Labour Force Survey 2014 Ad Hoc module (LFS 2014 AHM) was used in this analysis. The Spanish LFS is a quarterly survey that has been carried out since 1964 and that is based upon a sample of some 60,000 households amounting to a population of close to 180,000 people. It provides ample information on labour market developments and household characteristics. In 2014 a special module obtained in-depth information about the foreign-born population. In this module one sixth of the total sample was asked a number of questions about migration experience. Along with other information about migrants' characteristics and projects, the survey included data on their language skills. Because only those born outside Spain were supposed to answer this part of the LFS, the final sample includes 6,795 people.

This data was used to analyse native and foreign-born populations between 16 and 64 years old who are active in the labour market. The dependent variables in the analysis are the probability of being employed for 24,377 men and for 21,363 women. The reference category is native Spanish active population, both employed and unemployed. For the subsample formed by people who are employed $(19,085$ men and 16,327 women), the dependent variable is the probability of avoiding very low skilled occupations, that is, the probability of working in occupations other than those located in the lowest levels of the occupational pyramid ${ }^{2}$. The reference category is the native Spanish employed population.

2. The occupations included in the lowest segment are: domestic service workers, cleaners, assistants in food preparation, garbage collection workers, street vendors, and other labourers in services, agriculture, forestry, fishing, construction and mining, manufacturing industries, and transport. 
The main independent variable is the ability to speak Spanish. This is a selfreported variable that classifies people into one of four categories on the basis of their Spanish skills: mother tongue or native speaker, advanced level, intermediate level, and beginner or no skills. For some analyses, this variable was modified and treated as dichotomous, separating people with an advanced or high level from the rest (low level). The second independent variable comprises educational level, which was classified in 5 categories: primary or less, lower secondary, lower vocational training, upper secondary, upper vocational training and university.

In order to test the proposed hypotheses, logistic regression models were estimated and average marginal effects are presented. Empirical analysis consisted of two steps. First, models of the probability of being employed and the probability of being in a qualified occupation are estimated. These models include language skills as independent variables, where migrants with one of the four different language levels are compared to natives.

Second, the analysis is replicated for migrants alone by separating the estimates for people with high language skills and low language skills in order to capture the different returns on human capital for each group and to capture the complementary or substitution relationship that may exist between language skills and educational attainment. The active migrant population sample amounts to 2,111 men and 2,178 women, and the sample of those in employment amounts to 1,434 men and 1,498 women.

Each model was estimated separately for men and women because of the different effects (unique to the Spanish context) that the structure of the labour market has on each sex. Also, models are controlled for age, for whether or not the immigrants have Spanish nationality, and for the immigrants' potential time in the labour market (years since arrival).

\section{Descriptive analysis}

The descriptive data on these variables are presented below. Figure 2 shows the distribution of different levels of Spanish fluency among the foreign-born population of different continental origins. The majority of native speakers come from Latin America and, to a lesser extent, from the other EU-15 nations. Relatively low levels of fluency are found among immigrants from Asia and Africa compared with the other continents.

In the international comparative perspective provided by the OECD, despite the weight of Romanian immigrants, whose native language is related to Spanish, differences in literary proficiency scores between native Spanish speakers and adults who speak it as foreign language are about the same as the average scores 
among OECD countries (OECD 2013). Among the many factors affecting immigrants' acquisition of the host language (Ipshording 2015), it is very likely that, in the Spanish case, low educational levels and the lack of an explicit policy for linguistic integration have kept these scores lower than they might have been.

Figure 3 presents the distribution of the foreign-born population who participate in the labour market according to their fluency in Spanish and their educational level. Higher weights of native speakers are found among university and vocational education graduates than among immigrants with primary or secondary education. Taking together native speakers (or those whose mother tongue is Spanish) and people with an advanced level of Spanish, significant differences in educational level appear. Over 80 per cent of immigrants with university or upper vocational education have at least advanced Spanish, while 60 per cent of those who have primary education or less are beginners or report intermediate levels of the host country language.

Figure 2. Spanish level among foreign-born population, by origin (2014)

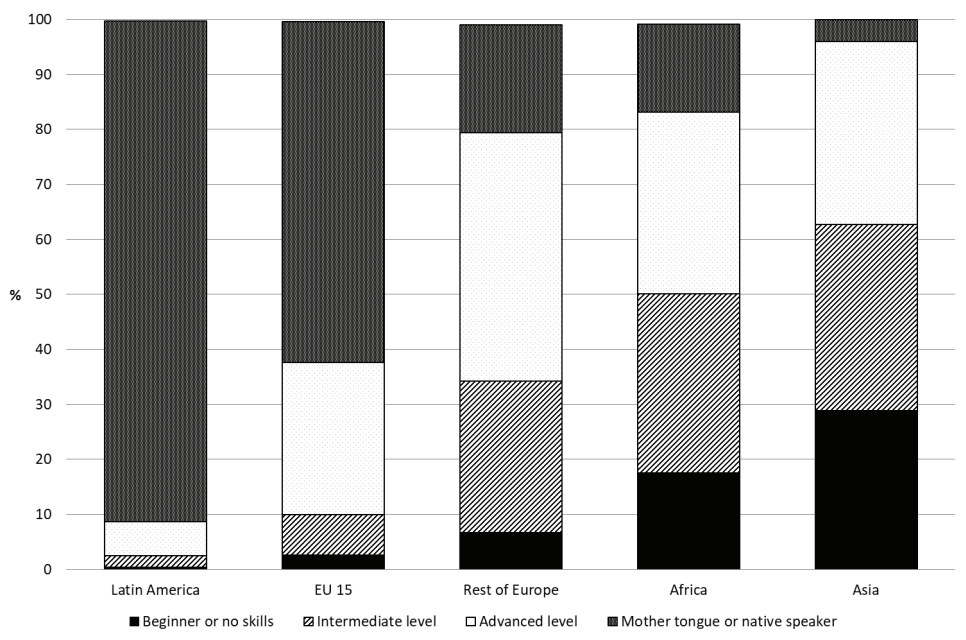

Source: Authors' own from LFS 2014 AHM. 
Figure 3. Spanish level among active foreign-born population by education level (no Hispanic origin) (2014)

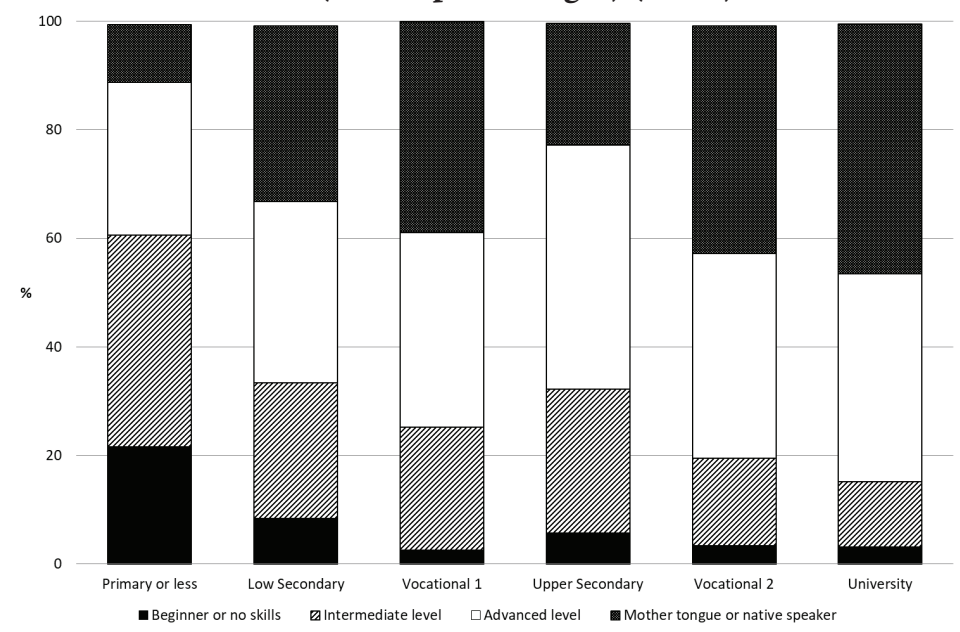

Source: Authors' own from LFS 2014 AHM.

\section{Results}

Figure 4 shows results indicating that for the foreign-born population who participate in the labour market, the probability of being employed is related to language skills. On the one hand, the results illustrate that the probability of being employed is lower for all groups born abroad than for native Spanish people (reference category). Still, migrants who speak Spanish as a mother tongue or as native speakers are less disadvantaged than other immigrants. Among women, migrants with the best language skills do not show any significant difference in comparison with native Spanish people. On the other hand, migrants with poor language skills (beginners or no skills) present the worst results as regards the probability of being employed. While men with good language skills have a 5 per cent lower probability of being employed than natives, among men with no language skills this difference is 8 per cent. Among women, those who report low levels of Spanish have a probability of being employed that is between 7 and 8 per cent lower than that of native Spanish population.

Figure 5 presents the results regarding the influence of Spanish language levels on the likelihood of avoiding very low-level jobs 5. These results take into account the employed population only. Coefficients represent the probability of avoiding the lowest level occupations for working immigrants. The significant (but scant) results indicate that immigrants have a lower probability of avoiding these occupations compared with Spanish workers. Also, the migrants' level of 
Spanish does not seem to affect the probability differentials (e.g. among female workers, those who speak like a native have the same negative differential as those with an intermediate level of Spanish).

Figure 4. Average marginal effects (AME) logit on the probability of being employed among active foreign-born population (ref. Hispanic origin)

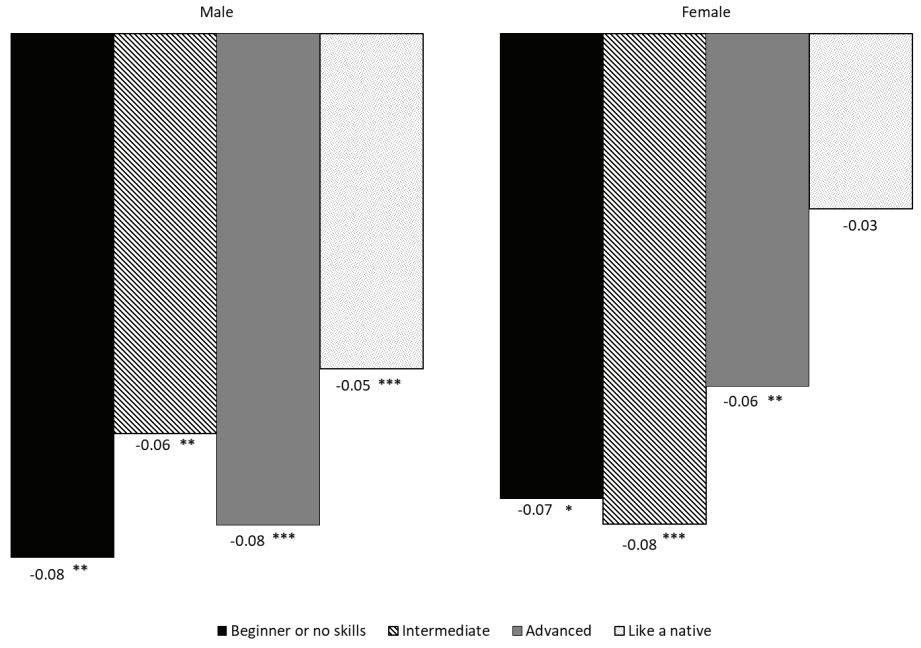

Source: Authors' own from LFS 2014 AHM.

Figure 5. Average marginal effects (AME) logit on the probability of working in occupations other than the very low-skilled

Male

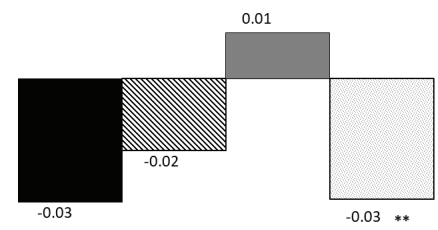

Female

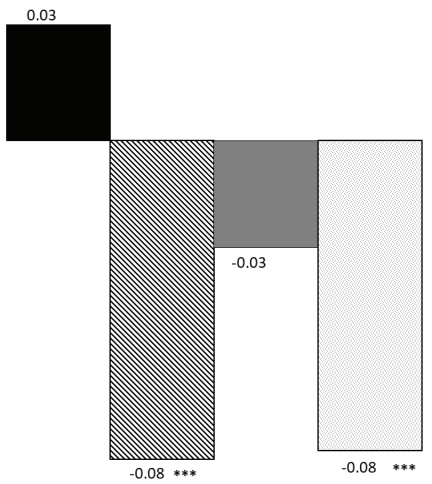

Source: Authors' own from LFS 2014 AHM. 
The second step of the analysis consisted of studying the interaction between language skills and the educational level. To do so, separate logistic regression models were estimated for migrants with high level language skills (mother tongue, native and advanced) and for those with low level skills (all the rest). The results are presented below.

Among male participants in the labour market, the results support the complementarity hypothesis. According to the estimates, men with good language skills obtain substantial returns on their educational level in terms of employment (Figure 6). For example, the probability of being employed is 31 per cent higher for migrants with a university degree than for migrants with primary education or less. However, the results suggest that migrants without Spanish language skills are not able to translate their educational level into employment advantages. Within this group, there is no difference in the probability of being employed between migrants with different educational levels and migrants with primary or less. Only migrants with upper secondary education seem to have a significantly higher probability of being employed than the group with the lowest education level (16 per cent higher). Thus, it seems that male migrants need to have a good command of Spanish if they are to reap a return on their educational investments.

Regarding the relationship between Spanish and education for immigrant women, the results are quite different from those of men. Educational levels have no effects on employment among women with good Spanish. Among those with a low level of Spanish, women with an upper vocational education have an employment probability that is 58 per cent higher than that of women with only primary education. This result could be interpreted in line with Bernardi, Garrido and Miyar (2011), who report significant employment differences between immigrant men and women, pointing out that immigrant women in the Spanish labour market tend to hold jobs that do not require educational components. The fact that no significant results were obtained for women with university degrees could be thus explained.

Figure 7 analyses the effect of Spanish language level on employment prospects and whether it complements education level as a resource. The results indicate that, among immigrant men, Spanish is not necessarily a significant complementary resource for obtaining returns on educational investment. Educational differences are significant both for men with a low or high level of Spanish. Therefore, education helps all men to access jobs that are higher up the occupational pyramid, regardless of their fluency in Spanish. However, immigrant women show a very different result, since only those with good Spanish are able 
to obtain significant returns on their level of education. Among the group with poor Spanish, the probability of avoiding low-skilled jobs is greater for university graduates than for women with primary education, but other educational differences seem to have little benefit in this regard. Thus, language competence is much less important as a complement to education for immigrant women than it is for immigrant men.

\section{Limitations}

Finally, it is necessary to discuss the limitations of this analysis. First of all, the source of data provides self-reported information on levels of Spanish among the immigrant population. In this regard, an alternative formulation to the considerations of fluency, levels or skills in Spanish could be that of selfconfidence in this language. Second, the data do not control for endogeneity, since no instrumental variable has been found that relates solely to language skills and not to labour market outcomes. For example, age at arrival, used in Budría et al.(2018) following Bleakley and Chin (2004), is known to be a determinant of labour market outcomes. Third, there could also be problems derived from heteroscelasticity or from the possibility that unobservable characteristics correlated with language proficiency could relate to self-selection into employment. If this problem existed it would affect the estimates regarding the effect of language on occupational status.

Figure 6. Average marginal effects (AME) logit on the probability of being employed among active foreign-born population (ref. primary education or less)

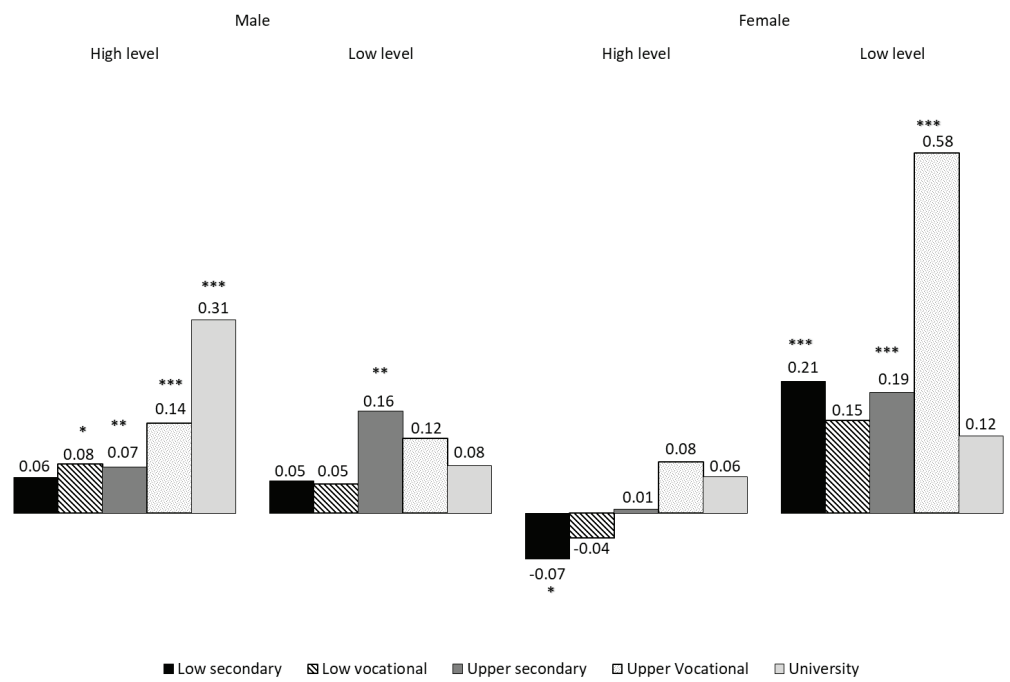

Source: Authors' own from LFS 2014 AHM. 
Figure 7. Average marginal effects (AME) logit on the probability of working in occupations other than the very low-skilled: Spanish level and education

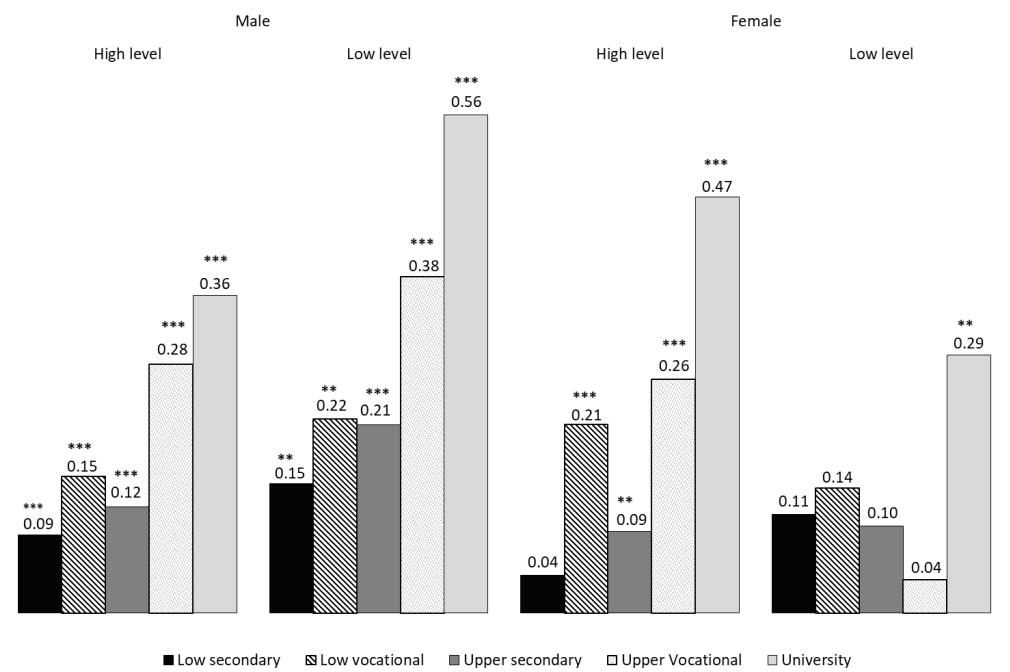

Source: Authors' own from LFS 2014 AHM.

\section{Discussion and conclusions}

The results obtained are particularly interesting for two reasons. On one hand, they refer to a Southern European country that has recently received a large number of immigrants with characteristics that condition their ability to achieve success in the labour market. These characteristics include a very large presence of immigrants with Spanish as their mother tongue and the large proportion of low-skilled jobs occupied by immigrants. On the other hand, the results bring knowledge of these achievements up to date and introduce differences compared with the data found in most of the available research, which usually focuses more on the economic growth cycle based on 2007 data.

The transferability of human capital is one of the main concerns regarding the assimilation of immigrants into host societies. This paper has tried to bring some evidence regarding the main factors that can shape that process and has presented some evidence about how micro-factors are not enough to explain success in the labour market for immigrants. Indeed, results show that, even if language skills facilitate access to employment for both male and female migrants in the Spanish labour market, their effect in combination with educational levels differs for the male and female labour markets. 
While language skills are found to have a complementary effect on educational level for male migrants, the data obtained on immigrant women's access to employment appear to show a substitution effect. For this group, the results show that education increases the probability of gaining employment only among women with low levels of Spanish and that it thus substitutes language skills as a resource.

However, when employment quality is analysed, measured by occupational levels, the results change for men and women. Levels of Spanish seem to be of little importance regarding the returns on educational investment for men, but they have a significant effect on those of women. Among female workers, education makes a difference only if their level of Spanish is good.

A plausible explanation for this divergence in the effect of language skills can be the different levels of segmentation of the labour market. Because the occupations available for women are mainly in the services sector, it may that in many (e.g. the domestic service) language skills substitute education when it comes to accessing employment. However, once the immigrant is working, education levels only have an important effect on their capacity to avoid very low level occupations if they are combined with language fluency.

The results suggest that institutional factors such as the configuration of the Spanish labour market are key to understanding the factors that support employment-related integration. When there is a shortage of occupations that migrants can access, the potential effect of different aspects of the human capital (education) is rather limited and the synergies that these different aspects generate are wasted. However, further research on the nature of employment and the transferability of human capital through language skills is needed.

\section{References}

Alonso, J. A., and Gutiérrez, R. (2010).Emigración y lengua. Madrid: Editorial Ariel-Fundación Telefónica, 101-159.

Adsera, A., and Pytrikova, M. (2015). "The role of language in shaping international migration". The Economic Journal, 125 (586): 49-81

Amuedo-Dorantes, C., and De La Rica, S. (2007). "Labour Market Assimilation of Recent Immigrants in Spain”. British Journal of Industrial Relations, 45(2): 257-285.

Basilio, L., and Bauer, TH. K. (2010),"Transferability of Human Capital and Immigrant Assimilation: an Analysis for Germany". IZA Discussion Paper No. 4716. 
Bleakley, H.; Chin, A. (2004) "Language skills and earnings: evidence from childhood immigrants". Rev Econ Stat 86:481-496.

Bentolila, S.; Dolado, J. J., and Jimeno, J. F. (2012). "Reforming an InsiderOutsider Labour Market: The Spanish Experience". FEDEA Working Papers 2012-1.

Berman, E.; Lang, K. and Siniver, E.(2003): "Language-skill complementarity: returns to immigrant language acquisition". Labour Economics, vol. 10(3): 265-290.

Bernardi, F; Garrido, L. and Miyar, M. (2011). "The Recent Fast Upsurge of Immigrants in Spain and Their Employment Patterns and Occupational Attainment". International Migration, 49(1): 148-187.

Blázquez, M. and S. Rendón (2012): "Over-education in multilingual economies: evidence from Catalonia". International Migration, 52 (6): 149164.

Budría, S., and Swedberg, P. (2015). "The impact of language proficiency on immigrants' earnings". Revista de Economía Aplicada, 23(67): 63-91.

Budría, S.; A. Colino, and C.M. de Ibarreta (2018). "The impact of host language proficiency on employment outcomes among immigrants in Spain". Empirica:1-28. <https://doi.org/10.1007/s10663-018-9414-x>.

Cebolla, H. and González Ferrer, A. (coords.) (2013). Inmigración: ¿integración sin modelo? Madrid: Alianza.

Chiswick, B. and Miller, P. W. (1991). "Speaking, reading and earnings among low-skilled immigrants". Journal of Labour Economics. 9 (2), 149-170

Chiswick, B. and Miller, P. W. (1995). "The Endogeneity between Language and Earnings: International analysis". Journal of labour Economics 13:2: 246288.

Chiswick, B. and Miller, P. (2003): The Complementarity of Language and other Human Capital: Immigrant Earnings in Canada", Economics of Education Review, 22(5): 469-480.

Chiswick, B. R., and Miller, P.W. (2014). "International Migration and Economics of Language”. In: Chiswick, B. R., and Miller, P.W. Handbook of the Economics of International Migation. Amsterdam: Elsevier, 211-270.

Chiswick, B. R., \& Miller, P. W. (2009). The International Transferability of Immigrants' Human Capital". Economics of Education Review, 28 (2): 162 169.

Dustmann, Ch. (1994). "Speaking fluency, writing fluency and earnings of migrants". Journal of Population Economics, 7: 133-156. 
Dustmann, Ch., and Fabri, F. (2003)."Language Proficiency and the Labour Market Performance of Immigrants in the United Kingdom". Economic Journal, 113:695-717.

Dustmann, Ch., and Van Soest, A. V. (2001). "Language Fluency and Earnings: Estimation with Misclassified Language Indicators". The Review of Economics and Statistics, 83(4): 663-674.

Dustmann, Ch., and Van Soest, A. V+(2002).'Language and the Earnings of Immigrants', Industrial and Labour Relations Review, 55(3): 473-492.

Fernández, Y, C., and Ortega, C. (2008). "Labour Market Assimilation of Immigrants in Spain: Employment at the Expense of Bad Job-matches?". Spanish Economic Review, 10(2): 83-107.

Friedberg, R. M. (2000). "You can't take it with you? Immigrant Assimilation and the Portability of Human Capital". Journal of Labour Economics, 18 (2): $221-251$.

Grin, F. (2003), "Language Planning and Economics", Current Issues in Language Planning, vol. 4-1, 1-66.

González-Enríquez, C. and Triandafyllidou, A. (2009). "Introduction: Comparing the New Hosts of Southern Europe". European Journal of Migration and Law, 11: 109-118.

IsPHORDING, I. E. (2015), "What drives the language proficiency of immigrants? IZA World of Labour 177.

Heckmann, F, and Schnapper, D. (eds.) (2003). The integration of Immigrants in European Societies. Stuttgart* Lucius and Lucius.

Izquierdo, A. and Cornelius, A. A. (eds.) (2012). Políticas de control migratorio: Estudio comparado de España y EEUU. Barcelona: Bellaterra.

Li, Q. and Sweetman, A. (2014). "The quality of immigrant source country educational outcomes: Do they matter in the receiving country?". Labour Economics, 26: 81-93.

Lochmann, A.; Rapoport, H. and Speciale, B. (2018)."The Effect of Language Training on Immigrants' Economic Integration: Empirical Evidence from France”. IZA Discussion Papers No. 11331.

Mato, F. J., and Gutiérrez, R. (2010). "Logros labourales de los inmigrantes económicos en España: el papel de la lengua española”. En: Alonso, J. A. and Gutiérrez, R., op cit.: 101-159.

Miyar, M. (2011). La dinámica de la inmigración en España: Una década de llegadas y salidas. PhD dissertation.

Miyar, M., and Mato, F. J. (2010)“"Las habilidades lingüísticas en español de los inmigrantes”, in Alonso, J.A., and Gutiérrez, R. op cit.‡ 65-100. 
Muñoz De Bustillo, R.; Carrera, M., and Antón, J. I. (2009)."From guests to hosts: a first whole picture of immigrant-native wage differentials in Spain". Mimeo.

OECD (2013). OECD Skills Outlook 2013: First Results from the Survey of Adult Skills. Paris: OECD Publishing.

Sanromá, E.; Ramos, R., \& Simón, H. (2015)."How relevant is the origin of human capital for immigrant wages? Evidence for Spain”. Journal of Applied Economics, 18 (1): 149-172.

Simón, H.; Ramos, R. and Sanromá, E. (2011). "Occupational Mobility of Immigrants in a Low Skilled Economy: The Spanish Case". IZA Discussion Papers n ${ }^{\circ} 5581$.

Zimmerman, F. H. (2005). European Migration: What Do We Know? Oxford: Oxford University Press. 


\section{Annexes}

Table A1. Average marginal effects (AME) logit on the probability of being employed among active foreign-born population

\begin{tabular}{|c|c|c|c|c|c|c|c|}
\hline & & & Male & & & Fema & \\
\hline & & Coe & & Std. Err. & $\mathrm{Coe}$ & & Std. Err. \\
\hline Level of Spanish & $\begin{array}{l}\text { Spanish mother tongue } \\
\text { (ref.) }\end{array}$ & & & & & & \\
\hline & Like a native & -0.053 & $* * *$ & 0.016 & -0.028 & & 0.017 \\
\hline & Advanced & -0.078 & $* * *$ & 0.023 & -0.056 & $* *$ & 0.026 \\
\hline & Intermediate & -0.036 & ** & 0.026 & -0.078 & $* * *$ & 0.030 \\
\hline & Beginner or no skills & -0.083 & ** & 0.035 & -0.074 & * & 0.040 \\
\hline Educational level & Primary or less (ref.) & & & & & & \\
\hline & Lower secondary & 0.074 & $* * *$ & 0.008 & 0.056 & $* * *$ & 0.010 \\
\hline & Lower vocational & 0.146 & $* * *$ & 0.011 & 0.135 & $* * *$ & 0.012 \\
\hline & Upper secondary & 0.179 & $* * *$ & 0.011 & 0.164 & $* * *$ & 0.012 \\
\hline & Upper vocational & 0.240 & $* * *$ & 0.011 & 0.189 & $* * *$ & 0.013 \\
\hline & University & 0.292 & $* * *$ & 0.011 & 0.277 & $* * *$ & 0.011 \\
\hline Age & & 0.003 & $* * *$ & 0.000 & 0.005 & $* * *$ & 0.000 \\
\hline Spanish nationality & & 0.005 & & 0.010 & 0.010 & & 0.011 \\
\hline Years since arrival & & 0.003 & $* * *$ & 0.000 & 0.001 & $* *$ & 0.000 \\
\hline & No. of subjects & 24.377 & & & 21.363 & & \\
\hline & LR chi2(12) & 1773.25 & & & 1489.57 & & \\
\hline & Prob $>$ chi 2 & 0.0000 & & & 0.0000 & & \\
\hline & Log likelihood & 11867.418 & & & 10921.833 & & \\
\hline & Pseudo R2 & 0.0695 & & & 0.0638 & & \\
\hline
\end{tabular}


Table A2. Average marginal effects (AME) logit on the probability of working in occupations other than the very low-skilled

\begin{tabular}{|c|c|c|c|c|c|c|c|}
\hline \multirow{3}{*}{ Level of Spanish } & \multirow{3}{*}{$\begin{array}{l}\text { Spanish mother tongue } \\
\text { (ref.) }\end{array}$} & \multicolumn{3}{|c|}{ Male } & \multicolumn{3}{|c|}{ Female } \\
\hline & & \multicolumn{2}{|c|}{ Coef. } & \multirow[t]{2}{*}{ Std. Err. } & \multicolumn{2}{|c|}{ Coef. } & \multirow[t]{2}{*}{ Std. Err } \\
\hline & & & & & & & \\
\hline & Like a native & -0.029 & $* *$ & 0.012 & -0.076 & $* * *$ & 0.015 \\
\hline & Advanced & 0.011 & & 0.017 & -0.026 & & 0.023 \\
\hline & Intermediate & -0.017 & & 0.018 & -0.078 & $* * *$ & 0.026 \\
\hline & Beginner or no skills & -0.030 & & 0.023 & 0.028 & & 0.037 \\
\hline \multirow{6}{*}{ Educational level } & Primary or less (ref.) & & & & & & \\
\hline & Lower secondary & 0.035 & $* * *$ & 0.006 & 0.005 & & 0.008 \\
\hline & Lower vocational & 0.075 & $* * *$ & 0.008 & 0.136 & $* * *$ & 0.011 \\
\hline & Upper secondary & 0.091 & $* * *$ & 0.008 & 0.161 & $* * *$ & 0.010 \\
\hline & Upper vocational & 0.127 & $* * *$ & 0.009 & 0.201 & $* * *$ & 0.012 \\
\hline & University & 0.221 & $* * *$ & 0.013 & 0.376 & $* * *$ & 0.013 \\
\hline Age & & 0.002 & $* * *$ & 0.000 & -0.002 & $* * *$ & 0.000 \\
\hline Spanish nationality & & -0.031 & $* * *$ & 0.007 & -0.094 & $* * *$ & 0.010 \\
\hline \multirow[t]{6}{*}{ Years since arrival } & & 0.000 & & 0.000 & -0.001 & ** & 0.000 \\
\hline & No. of subjects & 19.085 & & & 16.327 & & \\
\hline & LR chi2(12) & 1264.61 & & & 3412.62 & & \\
\hline & Prob $>$ chi 2 & 0.0000 & & & 0.0000 & & \\
\hline & Log likelihood & 4788.0324 & & & 5766.0623 & & \\
\hline & Pseudo R2 & 0.1167 & & & 0.2283 & & \\
\hline
\end{tabular}




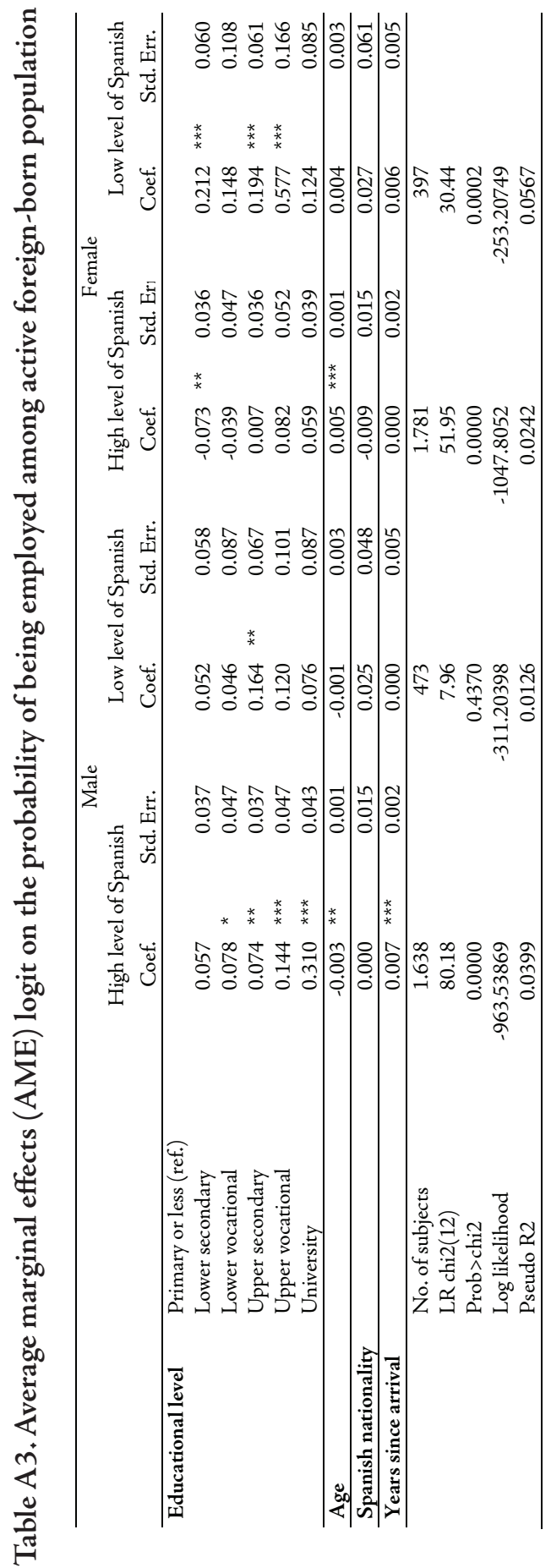




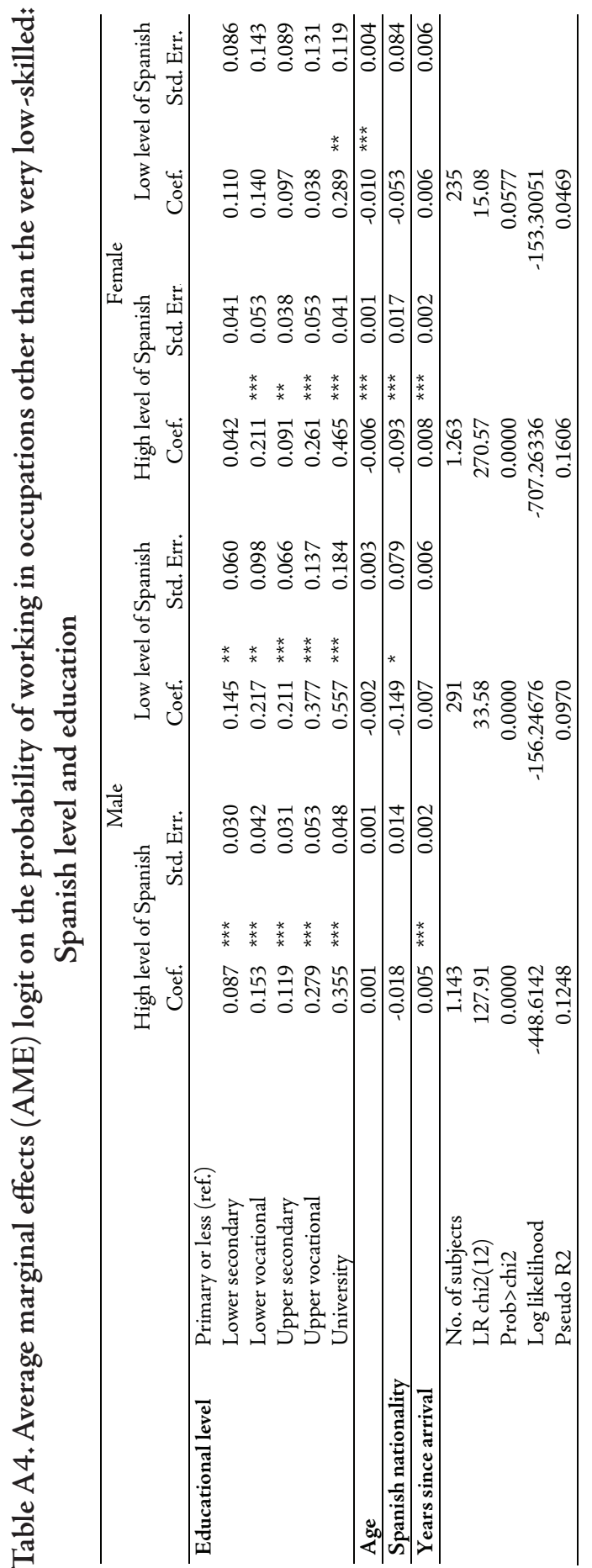

